\title{
Phenotypical characterization in Plasmopara halstedii (sunflower downy mildew) isolates of several races
}

\begin{abstract}
Nachaat Sakr ${ }^{1}$
Abstract: Sakr, N. 2015. Phenotypical characterization in Plasmopara halstedii (sunflower downy mildew) isolates of several races. Bot. Complut. 39: 7-18.

Phenotypic variation (morphological and pathogenic characters), and genetic variability were studied in 50 isolates of seven Plasmopara halstedii (sunflower downy mildew) races 100, 300, 304, 314, 710, 704 and 714. There were significant morphological, aggressiveness, and genetic differences for pathogen isolates. However, there was no relationship between morphology of zoosporangia and sporangiophores and pathogenic and genetic characteristics for the races used in our study. Also, our results provided evidence that no relation between pathogenic traits and multilocus haplotypes may be established in P. halstedii. The hypothesis explaining the absence of relationships among phenotypic and genetic characteristics is discussed.
\end{abstract}

Key words: Helianthus annuus, morphology, multilocus haplotypes, obligate parasite, pathogenicity.

Resumen: Sakr, N. 2015. Caracterización fenotípica en aislados de varias razas de Plasmopara halstedii (mildiu del girasol). Bot. Complut. 39: 7-18.

Se ha estudiado la variación fenotípica (caracteres morfológicos y patógenos) y la variabilidad genética de 50 aislamientos de las razas 100 , 300, 304, 314, 710, 704 y 714 de Plasmopara halstedii (mildiu del girasol). Se han encontrado diferencias significativas en la morfología, la agresividad y las variaciones genéticas para los aislados patógenos. Sin embargo, no se ha encontrado relación entre la morfología de los zoosporangios y esporangióforos, y las características patogénicas y genéticas entre las razas estudiadas. También nuestros resultados aportan evidencia de que no existe relación entre los patógenos estudiados y los haplotipos con múltiples loci resistentes en $P$. halstedii. Se comenta la hipótesis explicativa de la ausencia de relaciones entre las características fenotípicas y genotípicas.

Palabras clave: Helianthus annuus, morfología, haplotipos con multiples loci, parásito obligado, patogenicidad.

\section{INTRODUCTION}

Sunflower downy mildew is caused by Plasmopara halstedii. It is diploid, homothallic, and can reproduce sexually and asexually. The sexual phase is required to produce over wintering propagules, but during the sunflower growing season from spring to autumn there can be several asexual generations (Tourvieille de Labrouhe et al. 2000, Sakr 2014). Historically, this Oomycete was originally described by Farlow in 1882 as Peronospora halstedii, the name referring to Halsted, who first collected it on Eupatorium purpureum. After a revision of the genus $P e$ ronospora, the fungus was renamed Plasmopara halstedii in 1888 (Berlese et De Toni), and this name has become generally accepted and conventionally used in many parts of the world (Sackston 1981). P. halstedii shows physio- logical races (pathotypes) capable of infecting a variable range of sunflower genotypes. In the last decades, new races of $P$. halstedii were discovered worldwide in the cultivation areas of sunflower (As-Sadi et al. 2011, Sakr 2014).

$P$. halstedii has long been considered as a single species complex with a broad host range showing infectivity to $>80$ genera of the Asteroideae and Cichorioideae subfamilies of the Asteraceae (Leppik 1966). Attempts have been made to split up the $P$. halstedii complex into various new taxa related to specific host species (Leppik 1966). However, cross infection studies for the determination of host specificity were mostly lacking in this process. As another concept, on the basis of pathological assessments and of morphological examinations, Novotelnova (1966) differentiated between species and forms according to artificial infection studies on annual and perennial Helian-

\footnotetext{
${ }^{1}$ Department of Agriculture, Syrian Atomic Energy Commission, Damascus, P.O. Box 6091, Syria. Previous address INRA-UBP, UMR 1095, 234 Avenue du Brézet, 63100 Clermont-Ferrand, France. snachaat@hotmail.com, snachaat@gmail.com

Recibido: 21 enero 2015. Aceptado: 3 febrero 2015.
} 
thus species, giving the name Plasmopara helianthi to the fungus, thought to be confined to the genus Helianthus, with further specialization on intrageneric taxa as formae speciales: f.sp. helianthi (downy mildew of sunflower), f.sp. perennis, and f.sp. patens. The species name Plasmopara helianthi is now regarded as taxonomically invalid, because its introduction by Novotelnova (1966) did not adhere to the rules of the International Code of Botanical Nomenclature (Gulya et al. 1997). Novotelnova (1966) differentiation between species and forms of this fungus on the basis of minor morphological traits is not convincing when facing the great variability of biometric characters observed even among sporangiophores and sporangia of single isolates of the pathogen (Delanoe 1972). However, the distinctiveness of the given micromorphological characters and the infection specificity was doubted and the epithet helianthi was widely abandoned.

Characterization of new phenotypic aspects (morphological and pathogenic characters), and genetic characteristics in an obligate parasite such as $P$. halstedii based on interactions with sunflower plants is of interest for its taxonomy. P. halstedii is characterized by a high level of evolutionary potential expressed by high virulence, aggressiveness and a great potential in developing new races (Tourvieille de Labrouhe et al. 2000, 2010; Sakr 2009, 2010, 2011a,b, 2012, 2014; Sakr et al. 2009, 2011; As-Sadi et al. 2011). For morphology in $P$. halstedii, Spring \& Thins (2004) found phenotypic limited tools for analyzing $P$. halstedii. Concerning genotypic diversity in $P$. halstedii, the interest of Internal Transcribed Spacer (ITS) (Spring et al. 2006) and Expressed Sequence Tag (EST) (Delmotte et al. 2008) sequences to characterize P. halstedii isolates has been showed, but races can still not be defined with certainty. However, As-Sadi et al. (2011) reported that genetic distance between four $P$. halstedii races can be detected using Single Nucleotide Polymorphisms (SNPs) discovered in CRN (a cell-death-inducing proteins that cause crinkling and necrosis phenotypes in the leaves of infected plants) effector sequences. In order to generate information about the phenotypic and genetic variability in $P$. halstedii, the aim of this study was to analyze morphological, genetic, and pathogenic characters for 50 P. halstedii isolates of seven races 100, 300, 304, 314, 704, 710 and 714 .

\section{MATERIALS AND METHODS}

Oomycete isolates and race identification. Fifty $P$. halstedii isolates used in this study were sampled in France and co- llected at INRA, Clermont-Ferrand. Manipulation of this quarantined pathogen followed European regulations (No 2003/DRAF/70). Pathogen isolates were sampled from naturally infected plants in sunflower parcels at Clermont-Ferrand by the Plant Protection Service during its annual downy mildew survey. Virulence profiles of all races (Table 1) were obtained according to the method described by Tourvieille de Labrouhe et al. (2000) which is based on the reaction of a series of differential lines. The $P$. halstedii isolates were multiplied on the same sunflower genotype in the same conditions, such that any original intra-isolate variability would be maintained to the same extent for the 50 isolates. In addition, the isolates are multiplied using their zoospores, which could be a continued source of new variability, even for originally single zoosporangium isolates. All the pathogenic (virulence and aggressiveness) tests were carried out in growth chambers regulated at $18 \mathrm{hrs}$ of light, $18^{\circ} \mathrm{C} \pm$ 1 and $\mathrm{RH}$ of $65-90 \%$.

Measurement of aggressiveness in isolates. To characterize aggressiveness criteria: percentage infection, latent period, sporulation density and reduction of hypocotyl length for 50 P. halstedii isolates (Sakr 2009, 2010, 2011a,b, 2012, 2014; Sakr et al. 2009, 2011), one INRA inbred line FU was used. It carried no $P l$ gene, but is known to a have high level of quantitative resistance (Tourvieille de Labrouhe et al. 2008). The index of aggressiveness of $P$. halstedii isolates was calculated as the ration of (percentage infection $\times$ sporulation density) / (latent period $x$ dwarfing). The index of aggressiveness of the $P$. halstedii isolate was used to summarize all values for two criteria on sunflower inbred lines ' $F U$ ' in one value to facilitate the comparison between the different $P$. halstedii isolates (Sakr 2012, 2014).

Morphological observations. After 13 days of infection of the sunflower inbred line 'FU', the zoosporangia and sporangiophores suspensions for 50 isolates were obtained by grouping all sporulated cotyledons in a small container and adding $1 \mathrm{ml}$ of physiological water for each cotyledon $(9 \mathrm{~g} \mathrm{NaCl}+1 \mathrm{~L}$ sterilized water). This slowed zoosporangia maturation to facilitate observations before liberation of zoospores (Sakr et al. 2007). Identification of form and measurement of size was carried out on 50 zoosporangia per treatment under a light microscope (magnification X400) with 2 replications. Zoosporangia size was calculated from an oval $\pi \times a \times b, a=1 / 2$ length, $b=1 / 2$ width. Furthermore, sporangiophore dimensions were observed by measuring 50 fresh sporangiophores in physiological water under a light microscope (magnification X400) with 2 replications.

DNA extraction and molecular typing. The 12 EST derived markers were sequenced by Giresse et al. (2007). In the current study, these markers were used because the other molecular markers were non-specific, insufficiently polymorphic within $P$. halstedii, and no genetic structure in $P$. halstedii populations was identified by using these markers (Giresse et al. 2007). GenBank accession numbers for 12 EST-derived genomic markers (Giresse et al. 2007) were presented as following: Pha6 CB174585, Pha39 CB174648, Pha42 CB174650, Pha43 CB174680, Pha54 CB174708, Pha56 CB174714, Pha74 
Table 1

Virulence profile of 50 Plasmopara haslstedii isolates on nine sunflower differencial lines. R: resistant=incompatible interaction. S: susceptible = compatible interaction. Data from: Tourvieille de Labroubuhe et al. 2000)

\begin{tabular}{|c|c|c|c|c|c|c|c|c|c|}
\hline \multirow[b]{2}{*}{ Isolates of $P$. halstedii } & \multicolumn{9}{|c|}{ Differential lines } \\
\hline & $\begin{array}{c}\text { D1 } \\
\text { Ha-304 } \\
\text { without } \\
\text { Pl gene }\end{array}$ & $\begin{array}{c}\text { D2 } \\
\text { Rha-265 } \\
\quad P l 2\end{array}$ & $\begin{array}{c}\text { D3 } \\
\text { Rha-274 } \\
\text { Pl }\end{array}$ & $\begin{array}{c}\text { D4 } \\
\text { PMI3 } \\
\text { PI(?) }\end{array}$ & $\begin{array}{c}\text { D5 } \\
\text { PM-17 } \\
\text { Pl(?) }\end{array}$ & $\begin{array}{c}\text { D6 } \\
803-1 \\
P l(?)\end{array}$ & $\begin{array}{c}\text { D7 } \\
\text { HAR-4 } \\
\text { Pl(?) }\end{array}$ & $\begin{array}{c}\text { D8 } \\
\text { QHP1 } \\
\text { Pl(?) }\end{array}$ & $\begin{array}{c}\text { D9 } \\
\text { Ha-335 } \\
P l 6\end{array}$ \\
\hline $\begin{array}{l}\text { MIL001 M2, MIL001 M3 } \\
\text { MIL001 M4, MIL001 M5 } \\
\text { MIL001 M6 }\end{array}$ & S & $\mathrm{R}$ & $\mathrm{R}$ & $\mathrm{R}$ & $\mathrm{R}$ & $\mathrm{R}$ & $\mathrm{R}$ & $\mathrm{R}$ & $\mathrm{R}$ \\
\hline $\begin{array}{l}\text { DU1842 M1, DU1842 M2 } \\
\text { DU1842 M3, DU1842 M4 } \\
\text { DU1842 M5 }\end{array}$ & S & S & $\mathrm{R}$ & $\mathrm{R}$ & $\mathrm{R}$ & $\mathrm{R}$ & $\mathrm{R}$ & $\mathrm{R}$ & $\mathrm{R}$ \\
\hline $\begin{array}{l}\text { DU1943 M1, DU1943 M2 } \\
\text { DU1943 M3, DU1943 M4 } \\
\text { DU1943 M5 }\end{array}$ & S & S & $\mathrm{R}$ & S & $\mathrm{R}$ & $\mathrm{R}$ & $\mathrm{R}$ & $\mathrm{R}$ & S \\
\hline $\begin{array}{l}\text { DU1767 M1, DU1767 M2 } \\
\text { DU1767 M3, DU1767 M4 } \\
\text { DU1767 M5 }\end{array}$ & S & S & $\mathrm{R}$ & $\mathrm{R}$ & $\mathrm{R}$ & $\mathrm{R}$ & $\mathrm{R}$ & $\mathrm{R}$ & S \\
\hline $\begin{array}{l}\text { MIL002 M1, MIL002 M2 } \\
\text { MIL002 M3, MIL002 M4 } \\
\text { MIL002 M5 }\end{array}$ & S & S & S & S & S & S & S & S & S \\
\hline $\begin{array}{l}\text { DU 1552, DU 1555, DU } 1564 \\
\text { DU 1571, DU 1635, DU } 1651\end{array}$ & S & S & S & S & $\mathrm{R}$ & $\mathrm{R}$ & $\mathrm{R}$ & $\mathrm{R}$ & $\mathrm{R}$ \\
\hline $\begin{array}{l}\text { DU 1659, DU 1670, DU } 1753 \\
\text { DU 1776, DU 1777, DU } 1782\end{array}$ & S & S & S & S & S & S & S & S & S \\
\hline DU 1839, DU 1845, DU 1865 & S & S & S & S & S & S & S & S & S \\
\hline $\begin{array}{l}\text { DU1915 M3, DU1915 M5 } \\
\text { DU1915 M6 }\end{array}$ & S & S & $S$ & S & $\mathrm{R}$ & $\mathrm{R}$ & $\mathrm{R}$ & $\mathrm{R}$ & S \\
\hline $\begin{array}{l}\text { DU1734 M1, DU1734 M2 } \\
\text { DU1734 M3, DU1734 M7 } \\
\text { DU1734 M8 }\end{array}$ & $S$ & $S$ & $S$ & $\mathrm{R}$ & $\mathrm{R}$ & $\mathrm{R}$ & $\mathrm{R}$ & $\mathrm{R}$ & S \\
\hline
\end{tabular}

CB174642, Pha79 CB174692, Pha82 CB174573, Pha99 CB174703, Pha106 CB174676, and Pha120 CB174660. For 50 isolates tested, DNA was isolated from infected plant tissue, and then the 12 polymorphic EST-derived markers were used to genotype $P$. halstedii isolates. The polygenetic relations between the 50 isolates were obtained by building a Neighbour-Joining (NJ) tree (Jin \& Chakraborty 1993) using Populations 1.2.28 Software (Librado \& Rozas 2009). A Bootstrap analysis was performed on 10.000 replicates.
Statistical analyses. All statistical analyses were performed using StatBox $6.7^{\circledR}$ (GimmerSoft) software. Before statistical analysis, the percentages were transformed using the Arcsines function. A normality test showed that the transformed variables were normaly distributed, so the values obtained were submitted to a oneway analysis of variance (ANOVA). The Newman-Keuls test (Snedecor $\&$ Gochran 1989) was used to compare the means at $P=0.05$. The sample correlation coefficients (Pearson $r$ ) were calculated using overall mean values per treatment at $P=0.05$ and $P=0.01$. 


\section{RESULTS}

Analysis of pathogenicity for 50 isolates. Table 2 presents aggressiveness data of $50 \mathrm{P}$. halstedii isolates. All isolates showed high percentage infection values and it varied between 90.6 and $100 \%$. The latent period ranged from 7.8 days for isolates DU1842 M4, DU1842M5 and DU1943M4 to 12.5 days for isolate DU1734M7. Sporulation density varied six fold: $3.91 \times 10^{5}$ zoosporangia were produced by cotyledons for isolate DU1915 M2 and $19.68 \times 10^{5}$ for isolate MIL001 M2. Diseased plants had hypocotyls with only one third the mean lengths of $P$. halstedii-free sunflower inbred line ' $F U$ ' $(30.85 \pm 0.6 \mathrm{~mm}$ and $90.0 \pm 2.3 \mathrm{~mm}$ respectively) whatever the isolate of $P$. halstedii. Hypocotyl length varied from $25.6 \mathrm{~mm}$ for isolate DU1915 M6 to $44.9 \mathrm{~mm}$ for isolate DU1943 M5. There were significant differences for index of aggressiveness $($ F-value $=44,099, P$-value $=0.0001)$ in sunflower downy mildew isolates. The mean index of aggressiveness varied between five-fold: 1.5 for isolates of race 714 and 7.04 for isolates of 8.3 for isolates of race 300. Isolates of races 300 and 304 (mean index of aggressiveness $=6.01$ ) were the most aggressiveness, followed by isolates of races 100 (mean index of aggressiveness $=4.88$ ) and 314 (mean index of aggressiveness $=3.98$ ), and isolates of races 714, 704 (mean index of aggressiveness $=1.92$ ) and 710 (mean index of aggressiveness $=2.3$ ) were the least aggressiveness.

Morphology of zoosporangia and sporangiophores. The results showed that the two forms most observed were oval and round, irrespective of the $P$. halstedii isolate (Fig. 1). The proportion of oval form varied from 37 to $94 \%$ and the zoosporangia size from 315 to $918 \mu^{2}$ (Table 3). The proportion of oval zoosporangia varied within the races; for example, for race 100, it varied from $87 \%$ to $94 \%$ and for race 710 it ranged from $37 \%$ to $92 \%$. Mean sporangiophore length was the highest in DU1767M3 isolate $(800.0 \mu \mathrm{m})$. The sporangiophore length ranged between 299.0 and $800 \mu \mathrm{m}$. Mean sporangiophore width was the largest in DU1767M1 isolate. The sporangial width varied from $4.3 \mu \mathrm{m}$ to $16.0 \mu \mathrm{m}$. Zoosporangia size also varied considerably within and between races, with no relation to form. The dimensions for zoosporangia sizes were recorded as following: 11.4-62.4 $\mu \mathrm{m}$ to $11.4-100.8 \mu \mathrm{m}$. Moreover, the dimensions of sporangiophores ranged significantly within and between races (Table 1). Regarding sporangiophores sizes, length varied from 299.0 to $800 \mu \mathrm{m}$ and width ranged from 4.3 to $16.0 \mu \mathrm{m}$. There was thus no relationship between morphology of zoosporangia and sporangiophores and virulence profiles of all races (Tables 1 and 3). All aggressiveness criteria (Table 2 ) were not correlated with both form or size of zoosporangia (Table 3$)(r=-0.135$ and $r=$ -0.123 for percentage infection, $r=0.053$ and $r=0.056$ for latent period, $r=0.179$ and $r=-0.250$ for sporulation density and $r=-0.127$ and $r=0.170$ for hypocotyl length), and length or width of sporangiophore (Table 3$)(r=$ -0.123 and $r=0.215$ for percentage infection, $r=0.064$ and $r=-0.207$ for latent period, $r=-0.277$ and $r=0.044$ for sporulation density and $r=0.117$ and $r=-0.041$ for hypocotyl length).

Molecular analysis. The combination of 12-EST derived markers revealed five multilocus haplotypes (MLH) among 50 P. halstedii isolates (Table 4). There was no intra-race genetic variation for all pathotypes tested. Races 100 and 710 were different for all genomic markers excepting Pha54. Furthermore, races 100, 300, 304 had the same genetic background. The Neighbour-Joining tree showed that races 714, 704 and 314 had an intermediary genetic position between races 100 and 710 (Fig. 2). Consequently, there were five genetically-identified haplotypes among $P$. halstedii isolates tested: haplotype of isolates of races 100,300 and 304, haplotype of isolates of race 314 , haplotype of isolates of race 704, haplotype of isolates of race 714, and haplotype of isolates of race 710 (Table 4 and Fig. 2).
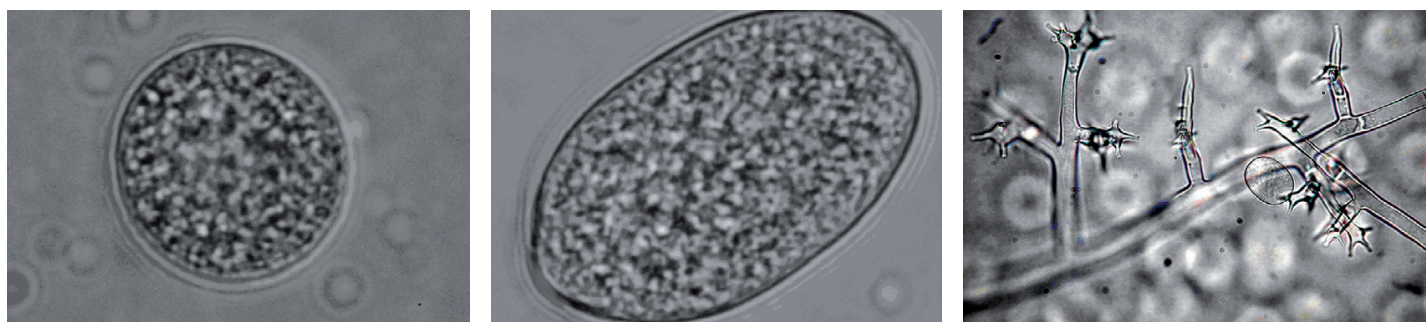

Fig. 1- Plasmopara halstedii zoosporangia forms and sporangiophores observed on sunflower inbred line 'FU': round (left), oval (center) and sporangiophore (right), the dimensions of zoosporangia and sporangiophores were magnified X400. 
Table 2

Aggressiveness values on sunflower inbred line 'FU' for 50 isolates of Plasmopara halstedii. a 60 plants per replication. ${ }^{\mathrm{b}} 10$ plants per replication. ${ }^{\mathrm{c}} 18$ counts per replication. ${ }^{\mathrm{d}} 10$ plants per replication, index of aggressiveness $=($ percentage infection $\times$ sporulation density $) /($ latent period $\times$ dwarfing $)($ Sakr 2009, 2010, 2011a,b, 2012, 2014; Sakr et al. 2009, 2011), F-tests (** $P=0.01)$, least significant differences LSD $(P=0.05)$.

\begin{tabular}{|c|c|c|c|c|c|c|}
\hline $\begin{array}{l}\text { Isolates } \\
\text { of } P \text {. halstedii }\end{array}$ & Race & $\begin{array}{c}\text { Percentage } \\
\text { infection }^{\mathrm{a}} \\
\text { Mean (\%) }\end{array}$ & $\begin{array}{c}\text { Latent } \\
\text { period }^{\mathrm{b}} \\
\text { Mean (days) }\end{array}$ & $\begin{array}{c}\text { Sporulation density } \\
\text { Mean } \\
\left(10^{5} \text { zoosporangia }\right. \\
\text { per cotyledon })\end{array}$ & $\begin{array}{l}\text { Hypocotyl } \\
\text { length }^{\mathrm{d}} \\
\text { Mean }(\mathrm{mm})\end{array}$ & $\begin{array}{l}\text { Index of } \\
\text { aggresiveness }\end{array}$ \\
\hline MIL001 M2 & 100 & 95 & 9.1 & 19.68 & 32.4 & 6.3 \\
\hline MIL001 M3 & & 100 & 9.3 & 12.70 & 28.7 & 4.8 \\
\hline MIL001 M4 & & 95.6 & 10.2 & 11.97 & 28.3 & 4.0 \\
\hline MIL001 M5 & & 97.2 & 8.9 & 13.16 & 27.9 & 5.2 \\
\hline MIL001 M6 & & 92.1 & 8.6 & 14.11 & 36.8 & 4.1 \\
\hline DU1842 M1 & 300 & 98.3 & 7.9 & 16.61 & 29.1 & 7.1 \\
\hline DU1842 M2 & & 98.8 & 8.1 & 17.20 & 28.4 & 7.4 \\
\hline DU1842 M3 & & 98.9 & 8.8 & 18.33 & 29.0 & 7.1 \\
\hline DU1842 M4 & & 99.4 & 7.8 & 14.03 & 33.6 & 5.3 \\
\hline DU1842 M5 & & 100 & 7.8 & 17.42 & 26.8 & 8.3 \\
\hline DU1943 M1 & 314 & 100 & 8.6 & 13.25 & 42.1 & 3.7 \\
\hline DU1943 M2 & & 100 & 8.5 & 12.75 & 40.9 & 3.7 \\
\hline DU1943 M3 & & 99.4 & 8.9 & 11.30 & 35.6 & 3.5 \\
\hline DU1943 M4 & & 98.9 & 8.2 & 18.27 & 39.7 & 5.6 \\
\hline DU1943 M5 & & 98.3 & 7.9 & 12.10 & 44.9 & 3.4 \\
\hline DU1767 M1 & 304 & 100 & 7.9 & 13.04 & 35.2 & 4.7 \\
\hline DU1767 M2 & & 98.9 & 8.7 & 13.60 & 27.9 & 5.5 \\
\hline DU1767 M3 & & 100 & 8.0 & 16.26 & 27.6 & 7.4 \\
\hline DU1767 M4 & & 100 & 8.6 & 15.31 & 26.2 & 6.8 \\
\hline DU1767 M5 & & 100 & 8.0 & 13.32 & 27.4 & 6.1 \\
\hline MIL002 M1 & 710 & 96 & 10.4 & 7.44 & 28.3 & 2.4 \\
\hline MIL002 M2 & & 95.6 & 11.8 & 5.45 & 32.8 & 1.3 \\
\hline MIL002 M3 & & 90.6 & 11.1 & 8.45 & 29.6 & 2.3 \\
\hline MIL002 M4 & & 95.6 & 10.3 & 8.25 & 26.1 & 2.9 \\
\hline MIL002 M5 & & 94.4 & 10.5 & 5.56 & 27.4 & 1.8 \\
\hline DU 1552 & & 100 & 9.7 & 5.6 & 37.8 & 1.5 \\
\hline DU 1555 & & 98.9 & 9.1 & 7.4 & 39.6 & 2.0 \\
\hline DU 1564 & & 99.4 & 9.3 & 7.4 & 36.9 & 2.1 \\
\hline DU 1571 & & 98.9 & 9.3 & 7.7 & 39.6 & 2.1 \\
\hline DU 1635 & & 99.3 & 8.6 & 11.9 & 38.7 & 3.6 \\
\hline DU 1651 & & 100 & 8.8 & 9.5 & 36.9 & 2.9 \\
\hline DU 1659 & & 100 & 8.7 & 9.7 & 28.8 & 3.9 \\
\hline DU 1670 & & 99.4 & 8.9 & 11.3 & 40.5 & 3.1 \\
\hline DU 1753 & & 100 & 8.8 & 5.7 & 32.4 & 2.0 \\
\hline DU 1776 & & 100 & 8.8 & 8.3 & 37.8 & 2.5 \\
\hline DU 1777 & & 100 & 8.5 & 7.2 & 37.8 & 2.2 \\
\hline DU 1782 & & 98.9 & 9.1 & 7.1 & 35.1 & 2.2 \\
\hline
\end{tabular}


Table 2 (cont.)

\begin{tabular}{|c|c|c|c|c|c|c|}
\hline $\begin{array}{l}\text { Isolates } \\
\text { of } P \text {. halstedii }\end{array}$ & Race & $\begin{array}{l}\text { Percentage } \\
\text { infection }^{\mathrm{a}} \\
\text { Mean (\%) }\end{array}$ & $\begin{array}{c}\text { Latent } \\
\text { period }^{\mathrm{b}} \\
\text { Mean (days) }\end{array}$ & $\begin{array}{c}\text { Sporulation density } \\
\text { Mean } \\
\left(10^{5} \text { zoosporangia }\right. \\
\text { per cotyledon })\end{array}$ & $\begin{array}{l}\text { Hypocotyl } \\
\text { length }^{\mathrm{d}} \\
\text { Mean (mm) }\end{array}$ & $\begin{array}{c}\text { Index of } \\
\text { aggresiveness }\end{array}$ \\
\hline DU 1839 & & 100 & 9.1 & 6.8 & 37.8 & 2.0 \\
\hline DU 1845 & & 97 & 9.6 & 5.8 & 36 & 1.6 \\
\hline DU 1865 & & 97 & 9.4 & 6.9 & 35.1 & 2.0 \\
\hline DU1915 M1 & 714 & 95.9 & 10.6 & 6.20 & 28.3 & 2.0 \\
\hline DU1915 M2 & & 95.5 & 11.9 & 3.33 & 28.2 & 1.0 \\
\hline DU1915 M3 & & 95 & 10.2 & 3.91 & 29.6 & 1.2 \\
\hline DU1915 M5 & & 98.3 & 11.5 & 4.07 & 26.7 & 1.3 \\
\hline DU1915 M6 & & 91.1 & 11.2 & 7.62 & 25.6 & 2.4 \\
\hline DU1734 M1 & 704 & 95 & 11.0 & 4.37 & 26.6 & 1.4 \\
\hline DU1734 M2 & & 98.3 & 10.9 & 7.72 & 26.5 & 2.6 \\
\hline DU1734 M3 & & 95.6 & 10.5 & 5.84 & 26.8 & 2.0 \\
\hline DU1734 M7 & & 97.8 & 12.5 & 5.58 & 28.3 & 1.5 \\
\hline DU1734 M8 & & 95.6 & 11.6 & 8.07 & 31.0 & 2.1 \\
\hline $\mathrm{F}$ isolates & & $3.03 * *$ & $55.47^{* *}$ & $12.39 * *$ & $5.46 * *$ & \\
\hline LSD & & 25.6 & 0.53 & 357 & 6.12 & \\
\hline
\end{tabular}

\section{DISCUSSION}

For Plasmopara halstedii, it has not yet been possible to use molecular differences to define pathogenicity characteristics (As-Sadi et al. 2011), and direct race identification of $P$. halstedii is not yet possible (Sakr 2014); so, it appeared useful to continue phenotypic (morphological and pathogenic characters) and genetic studies. Bearing this in mind, pathogenic, morphological and genetic characteristics were identified for $50 P$. halstedii isolates of several races based on interactions with sunflower plants.

Differences in aggressiveness of $P$. halstedii races are indicated when pathogen isolates vary in the amount of damage that they cause in sunflower plants. High percentage infection, short latent period, high sporulation density, and significant reduction in the length of the hypocotyl represent high aggressiveness (Sakr 2009, 2011 a,b, 2012, 2014; Sakr et al. 2009, 2011). It is possible that variability between $P$. halstedii isolates used is due to the origin of pathogen isolates used in this study (Tables 1 and 2). These isolates belong to several races and may be found to be an effect of additional virulence genes in $P$. halstedii isolates as observed for the same pathosystem (Sakr 2009, 2011a,b, 2012, 2014; Sakr et al. 2009) and another oomycete $P$. infestans (Montarry et al. 2010).
From observations of 5000 zoosporangia and sporangiophores, isolates showed different proportions of the oval form, zoosporangia size, and sporangiophores dimension (Table 3). Both the effects of host plant genotype and the different isolates used in other studies may explain the different measurements reported. For zoosporangia sizes, the dimensions recorded as following: $30-33 \mu \mathrm{m}$ to $36-57 \mu \mathrm{m}$ in Nishimura (1922), 14-20 $\mu \mathrm{m}$ to $18-30 \mu \mathrm{m}$ according to Hall (1989) and 12-16 $\mu \mathrm{m}$ to 27-40 $\mu \mathrm{m}$ in Spring et al. (2003). Regarding sporangiophores sizes, Kulkarni et al. (2009) reported that sporangiophores length varied from 325 to 700 $\mu \mathrm{m}$ and sporangiophores width ranged from 5 to $10 \mu \mathrm{m}$.

There was no intra-race genetic variation (Table 4), but five genetically-identified haplotypes were detected among $P$. halstedii isolates of all races (Fig. 2). Our results observed genetic distances between two races 100 and 710 in agreement with the conclusions of Delmotte et al. (2008), Sakr (2011a) and As-Sadi et al. (2011). By using the same EST-derived markers, Delmotte et al. (2008) and Sakr (2011a) found that races 100, 300 and 304 had the same genetic clade as observed in our study (Fig. 2). However, As-Sadi et al. (2011) reported that certain SNPs might allow for clear differentiation between races 304 and 100, which has not been detected in our work (Fig. 2) and previously studies (Delmotte et al. 2008, Sakr 2011a). 


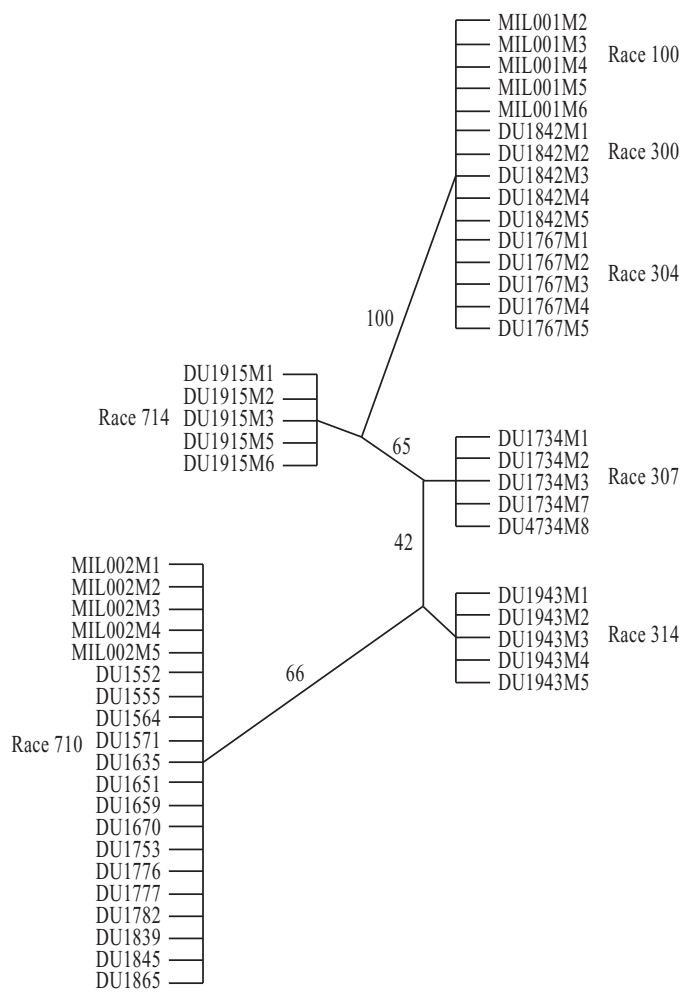

Fig. 2- Phylogenetic tree according to Neighbour-Joining analysis of 12 EST-derived markers. Figures on branches indicate bootstrap values (10.000 replicates).
Delmotte et al. (2008) grouped races 710, 704 and 714 together in the same genetic clade; however, this association was not identified in the present work and in previously analyses (Sakr 2011a). Either the isolates used in our study were different from the ones used by Delmotte et al. (2008), or the intrarace variance in the EST-derived marker may explain the different results reported.

There was no relationship between morphology of zoosporangia and sporangiophores (Table 3 ) and virulent (Table 1) and aggressiveness characteristics (Table 2) for the races used in our study. In accordance with our results, for another oomycete, Phytophthora capsici, Islam et al. (2004) did not find any relationship between groups of isolates characterized for their growth patterns on artificial medium and their pathogenicity. However, for the same pathosystem, Sakr (2011b) found a relationship between another phenotypic character (viability of zoosporangia) and aggressiveness in $P$. halstedii. This is in contrast with the results of De Wet et al. (2003) who observed morphological differences between strains of Sphaeropsis sapinea, which divided them into three morphotypes ( $\mathrm{A}, \mathrm{B}$ and $\mathrm{C}$ ) that presented differences in pathogenicity (virulence and aggressiveness). Also, in the pathosystem Sclerotinia sclerotiorum / rapeseed and mustard, Ghasolia \& Asha (2007) described nine groups based on morphological characters which were divided into two series according to degree of aggressiveness.

Table 3

Morphometric data of zoosporangia and sporangiophores obtained on sunflower genotype 'FU' for 50 isolates of Plasmopara halstedii. ${ }^{a} 50$ zoosporangia per replication. ${ }^{\mathrm{b}} 50$ zoosporangia per replication. ${ }^{\mathrm{c}} 50$ sporangiophores per replication. ${ }^{\mathrm{d}} 50$ sporangiophores per replication. F-tests $(* * P=0.01)$, least significant differences LSD $(P=0.05)$.

\begin{tabular}{|c|c|c|c|c|c|}
\hline $\begin{array}{l}\text { Isolates } \\
\text { of } P \text {. halstedii }\end{array}$ & Race & $\begin{array}{c}\% \text { of oval } \\
\text { zoosporangiaa }\end{array}$ & $\begin{array}{l}\text { Size of zoosporangia } \\
\text { in } \mu \mathrm{m}^{2 \mathrm{~b}}\end{array}$ & $\begin{array}{l}\text { Sporangiophore } \\
\text { length } \\
(\mu \mathrm{m})^{c}\end{array}$ & $\begin{array}{l}\text { Sporangiophore } \\
\text { width } \\
(\mu \mathrm{m})^{\mathrm{d}}\end{array}$ \\
\hline MIL001 M2 & 100 & 87 & 315.8 & 325.9 & 12.3 \\
\hline MIL001 M3 & & 94 & 434.9 & 550.2 & 15.1 \\
\hline MIL001 M4 & & 88 & 392.9 & 715.9 & 10.9 \\
\hline MIL001 M5 & & 91 & 418.7 & 660.2 & 8.7 \\
\hline MIL001 M6 & & 90 & 432.2 & 489.3 & 6.9 \\
\hline DU1842 M1 & 300 & 88 & 398.0 & 333.8 & 5.1 \\
\hline DU1842 M2 & & 89 & 511.7 & 568.2 & 4.3 \\
\hline DU1842 M3 & & 68 & 436.4 & 663.6 & 7.7 \\
\hline DU1842 M4 & & 82 & 315.2 & 785.2 & 14.8 \\
\hline DU1842 M5 & & 89 & 381.4 & 559.3 & 12.3 \\
\hline DU1943 M1 & 314 & 93 & 424.8 & 663.5 & 9.7 \\
\hline
\end{tabular}


Table 3 (cont.)

\begin{tabular}{|c|c|c|c|c|c|}
\hline $\begin{array}{l}\text { Isolates } \\
\text { of } P \text {. halstedii }\end{array}$ & Race & $\begin{array}{c}\% \text { of oval } \\
\text { zoosporangia }\end{array}$ & $\begin{array}{l}\text { Size of zoosporangia } \\
\text { in } \mu \mathrm{m}^{2 b}\end{array}$ & $\begin{array}{l}\text { Sporangiophore } \\
\text { length } \\
(\mu \mathrm{m})^{\mathrm{c}}\end{array}$ & $\begin{array}{l}\text { Sporangiophore } \\
\text { width } \\
(\mu \mathrm{m})^{\mathrm{d}}\end{array}$ \\
\hline DU1943 M2 & \multirow{9}{*}{304} & 86 & 425.4 & 489.3 & 6.3 \\
\hline DU1943 M3 & & 80 & 387.6 & 356.2 & 8.2 \\
\hline DU1943 M4 & & 56 & 372.0 & 689.3 & 10.9 \\
\hline DU1943 M5 & & 56 & 380.4 & 299.0 & 14.3 \\
\hline DU1767 M1 & & 86 & 394.0 & 478.6 & 16.0 \\
\hline DU1767 M2 & & 78 & 422.3 & 559.6 & 8.3 \\
\hline DU1767 M3 & & 90 & 505.2 & 800.0 & 6.5 \\
\hline DU1767 M4 & & 91 & 478.7 & 456.3 & 8.1 \\
\hline DU1767 M5 & & 63 & 344.7 & 765.3 & 9.6 \\
\hline MIL002 M1 & \multirow[t]{20}{*}{710} & 82 & 463.5 & 459.3 & 7.8 \\
\hline MIL002 M2 & & 92 & 513.3 & 569.3 & 6.6 \\
\hline MIL002 M3 & & 90 & 918.6 & 553.6 & 8.9 \\
\hline MIL002 M4 & & 37 & 352.9 & 440.4 & 12.0 \\
\hline MIL002 M5 & & 53 & 419.4 & 554.3 & 11.9 \\
\hline DU 1552 & & 77 & 558.5 & 636.9 & 15.2 \\
\hline DU 1555 & & 71 & 534.4 & 496.3 & 12.3 \\
\hline DU 1564 & & 61 & 510.9 & 444.5 & 11.0 \\
\hline DU 1571 & & 61 & 549.4 & 725.9 & 12.3 \\
\hline DU 1635 & & 83 & 551.6 & 563.6 & 14.3 \\
\hline DU 1651 & & 78 & 578.2 & 453.5 & 16.0 \\
\hline DU 1659 & & 73 & 600.4 & 660.3 & 12.3 \\
\hline DU 1670 & & 67 & 465.8 & 478.3 & 13.3 \\
\hline DU 1753 & & 72 & 547.1 & 698.5 & 14.5 \\
\hline DU 1776 & & 69 & 485.7 & 669.3 & 12.5 \\
\hline DU 1777 & & 74 & 513.4 & 559.6 & 14.6 \\
\hline DU 1782 & & 78 & 546.4 & 598.6 & 12.6 \\
\hline DU 1839 & & 78 & 518.5 & 785.6 & 14.9 \\
\hline DU 1845 & & 87 & 320.5 & 589.6 & 12.3 \\
\hline DU 1865 & & 68 & 497.4 & 489.3 & 9.96 \\
\hline DU1915 M1 & \multirow[t]{5}{*}{714} & 90 & 477.8 & 700.9 & 8.5 \\
\hline DU1915 M2 & & 90 & 477.8 & 456.3 & 7.6 \\
\hline DU1915 M3 & & 93 & 734.6 & 552.1 & 6.2 \\
\hline DU1915 M5 & & 86 & 374.6 & 456.3 & 5.0 \\
\hline DU1915 M6 & & 87 & 358.9 & 558.2 & 6.8 \\
\hline DU1734 M1 & \multirow[t]{5}{*}{704} & 74 & 505.4 & 335.6 & 7.4 \\
\hline DU1734 M2 & & 68 & 357.1 & 663.3 & 6.8 \\
\hline DU1734 M3 & & 68 & 314.3 & 712.3 & 8.1 \\
\hline DU1734 M7 & & 74 & 302.2 & 322.2 & 9.6 \\
\hline DU1734 M8 & & 89 & 436.9 & 455.9 & 6.0 \\
\hline $\mathrm{F}$ isolates & & $7.52 * *$ & $8.40 * *$ & $7.69 * *$ & $4.89 * *$ \\
\hline LSD & & 13.2 & 110.3 & 101.3 & 9.63 \\
\hline
\end{tabular}


Table 4

Multilocus haplotypes (MLH) characterized using 12 EST-derived genomic markers on 50 isolates of Plasmopara halstedii. Genetic markers are variants in the DNA code (known as alleles) that, alone or in combination, are associated with a specific phenotype, the values of two figures indicate to the alleles of 50 Plasmopara halstedii isolates for 12 EST-derived genomic markers. For each isolate, the race and the two alleles at each derived genomic marker were indicated.

\begin{tabular}{|c|c|c|c|c|c|c|c|c|c|c|c|c|}
\hline \multirow{2}{*}{$\begin{array}{l}\text { Isolates } \\
\text { of } P \text {. halstedii }\end{array}$} & \multicolumn{12}{|c|}{ EST-derived markers } \\
\hline & Pha6 & Pha39 & Pha42 & Pha43 & Pha54 & Pha56 & Pha 74 & Pha 79 & Pha82 & Pha99 & Pha106 & Pha120 \\
\hline MIL001 M2 & $2 / 2$ & $2 / 2$ & $1 / 1$ & $1 / 1$ & $1 / 1$ & $1 / 1$ & $1 / 1$ & $3 / 3$ & $2 / 2$ & $2 / 2$ & $1 / 1$ & $2 / 2$ \\
\hline MIL001 M3 & $2 / 2$ & $2 / 2$ & $1 / 1$ & $1 / 1$ & $1 / 1$ & $1 / 1$ & $1 / 1$ & $3 / 3$ & $2 / 2$ & $2 / 2$ & $1 / 1$ & $2 / 2$ \\
\hline MIL001 M4 & $2 / 2$ & $2 / 2$ & $1 / 1$ & $1 / 1$ & $1 / 1$ & $1 / 1$ & $1 / 1$ & $3 / 3$ & $2 / 2$ & $2 / 2$ & $1 / 1$ & $2 / 2$ \\
\hline MIL001 M5 & $2 / 2$ & $2 / 2$ & $1 / 1$ & $1 / 1$ & $1 / 1$ & $1 / 1$ & $1 / 1$ & $3 / 3$ & $2 / 2$ & $2 / 2$ & $1 / 1$ & $2 / 2$ \\
\hline MIL001 M6 & $2 / 2$ & $2 / 2$ & $1 / 1$ & $1 / 1$ & $1 / 1$ & $1 / 1$ & $1 / 1$ & $3 / 3$ & $2 / 2$ & $2 / 2$ & $1 / 1$ & $2 / 2$ \\
\hline DU1842 M1 & $2 / 2$ & $2 / 2$ & $1 / 1$ & $1 / 1$ & $1 / 1$ & $1 / 1$ & $1 / 1$ & $3 / 3$ & $2 / 2$ & $2 / 2$ & $1 / 1$ & $2 / 2$ \\
\hline DU1842 M2 & $2 / 2$ & $2 / 2$ & $1 / 1$ & $1 / 1$ & $1 / 1$ & $1 / 1$ & $1 / 1$ & $3 / 3$ & $2 / 2$ & $2 / 2$ & $1 / 1$ & $2 / 2$ \\
\hline DU1842 M3 & $2 / 2$ & $2 / 2$ & $1 / 1$ & $1 / 1$ & $1 / 1$ & $1 / 1$ & $1 / 1$ & $3 / 3$ & $2 / 2$ & $2 / 2$ & $1 / 1$ & $2 / 2$ \\
\hline DU1842 M4 & $2 / 2$ & $2 / 2$ & $1 / 1$ & $1 / 1$ & $1 / 1$ & $1 / 1$ & $1 / 1$ & $3 / 3$ & $2 / 2$ & $2 / 2$ & $1 / 1$ & $2 / 2$ \\
\hline DU1842 M5 & $2 / 2$ & $2 / 2$ & $1 / 1$ & $1 / 1$ & $1 / 1$ & $1 / 1$ & $1 / 1$ & $3 / 3$ & $2 / 2$ & $2 / 2$ & $1 / 1$ & $2 / 2$ \\
\hline DU1943 M1 & $1 / 1$ & $2 / 2$ & $1 / 1$ & $2 / 2$ & $1 / 1$ & $2 / 2$ & $2 / 2$ & $3 / 3$ & $2 / 2$ & $1 / 1$ & $2 / 2$ & $1 / 1$ \\
\hline DU1943 M2 & $1 / 1$ & $2 / 2$ & $1 / 1$ & $2 / 2$ & $1 / 1$ & $2 / 2$ & $2 / 2$ & $3 / 3$ & $2 / 2$ & $1 / 1$ & $2 / 2$ & $1 / 1$ \\
\hline DU1943 M3 & $1 / 1$ & $2 / 2$ & $1 / 1$ & $2 / 2$ & $1 / 1$ & $2 / 2$ & $2 / 2$ & $3 / 3$ & $2 / 2$ & $1 / 1$ & $2 / 2$ & $1 / 1$ \\
\hline DU1943 M4 & $1 / 1$ & $2 / 2$ & $1 / 1$ & $2 / 2$ & $1 / 1$ & $2 / 2$ & $2 / 2$ & $3 / 3$ & $2 / 2$ & $1 / 1$ & $2 / 2$ & $1 / 1$ \\
\hline DU1943 M5 & $1 / 1$ & $2 / 2$ & $1 / 1$ & $2 / 2$ & $1 / 1$ & $2 / 2$ & $2 / 2$ & $3 / 3$ & $2 / 2$ & $1 / 1$ & $2 / 2$ & $1 / 1$ \\
\hline DU1767 M1 & $2 / 2$ & $2 / 2$ & $1 / 1$ & $1 / 1$ & $1 / 1$ & $1 / 1$ & $1 / 1$ & $3 / 3$ & $2 / 2$ & $2 / 2$ & $1 / 1$ & $2 / 2$ \\
\hline DU1767 M2 & $2 / 2$ & $2 / 2$ & $1 / 1$ & $1 / 1$ & $1 / 1$ & $1 / 1$ & $1 / 1$ & $3 / 3$ & $2 / 2$ & $2 / 2$ & $1 / 1$ & $2 / 2$ \\
\hline DU1767 M3 & $2 / 2$ & $2 / 2$ & $1 / 1$ & $1 / 1$ & $1 / 1$ & $1 / 1$ & $1 / 1$ & $3 / 3$ & $2 / 2$ & $2 / 2$ & $1 / 1$ & $2 / 2$ \\
\hline DU1767 M4 & $2 / 2$ & $2 / 2$ & $1 / 1$ & $1 / 1$ & $1 / 1$ & $1 / 1$ & $1 / 1$ & $3 / 3$ & $2 / 2$ & $2 / 2$ & $1 / 1$ & $2 / 2$ \\
\hline DU1767 M5 & $2 / 2$ & $2 / 2$ & $1 / 1$ & $1 / 1$ & $1 / 1$ & $1 / 1$ & $1 / 1$ & $3 / 3$ & $2 / 2$ & $2 / 2$ & $1 / 1$ & $2 / 2$ \\
\hline MIL002 M1 & $1 / 1$ & $1 / 1$ & $2 / 2$ & $2 / 2$ & $1 / 1$ & $2 / 2$ & $2 / 2$ & $1 / 1$ & $1 / 1$ & $1 / 1$ & $2 / 2$ & $1 / 1$ \\
\hline MIL002 M2 & $1 / 1$ & $1 / 1$ & $2 / 2$ & $2 / 2$ & $1 / 1$ & $2 / 2$ & $2 / 2$ & $1 / 1$ & $1 / 1$ & $1 / 1$ & $2 / 2$ & $1 / 1$ \\
\hline MIL002 M3 & $1 / 1$ & $1 / 1$ & $2 / 2$ & $2 / 2$ & $1 / 1$ & $2 / 2$ & $2 / 2$ & $1 / 1$ & $1 / 1$ & $1 / 1$ & $2 / 2$ & $1 / 1$ \\
\hline MIL002 M4 & $1 / 1$ & $1 / 1$ & $2 / 2$ & $2 / 2$ & $1 / 1$ & $2 / 2$ & $2 / 2$ & $1 / 1$ & $1 / 1$ & $1 / 1$ & $2 / 2$ & $1 / 1$ \\
\hline MIL002 M5 & $1 / 1$ & $1 / 1$ & $2 / 2$ & $2 / 2$ & $1 / 1$ & $2 / 2$ & $2 / 2$ & $1 / 1$ & $1 / 1$ & $1 / 1$ & $2 / 2$ & $1 / 1$ \\
\hline DU 1552 & $1 / 1$ & $1 / 1$ & $2 / 2$ & $2 / 2$ & $1 / 1$ & $2 / 2$ & $2 / 2$ & $1 / 1$ & $1 / 1$ & $1 / 1$ & $2 / 2$ & $1 / 1$ \\
\hline DU 1555 & $1 / 1$ & $1 / 1$ & $2 / 2$ & $2 / 2$ & $1 / 1$ & $2 / 2$ & $2 / 2$ & $1 / 1$ & $1 / 1$ & $1 / 1$ & $2 / 2$ & $1 / 1$ \\
\hline DU 1564 & $1 / 1$ & $1 / 1$ & $2 / 2$ & $2 / 2$ & $1 / 1$ & $2 / 2$ & $2 / 2$ & $1 / 1$ & $1 / 1$ & $1 / 1$ & $2 / 2$ & $1 / 1$ \\
\hline DU 1571 & $1 / 1$ & $1 / 1$ & $2 / 2$ & $2 / 2$ & $1 / 1$ & $2 / 2$ & $2 / 2$ & $1 / 1$ & $1 / 1$ & $1 / 1$ & $2 / 2$ & $1 / 1$ \\
\hline DU 1635 & $1 / 1$ & $1 / 1$ & $2 / 2$ & $2 / 2$ & $1 / 1$ & $2 / 2$ & $2 / 2$ & $1 / 1$ & $1 / 1$ & $1 / 1$ & $2 / 2$ & $1 / 1$ \\
\hline DU 1651 & $1 / 1$ & $1 / 1$ & $2 / 2$ & $2 / 2$ & $1 / 1$ & $2 / 2$ & $2 / 2$ & $1 / 1$ & $1 / 1$ & $1 / 1$ & $2 / 2$ & $1 / 1$ \\
\hline DU 1659 & $1 / 1$ & $1 / 1$ & $2 / 2$ & $2 / 2$ & $1 / 1$ & $2 / 2$ & $2 / 2$ & $1 / 1$ & $1 / 1$ & $1 / 1$ & $2 / 2$ & $1 / 1$ \\
\hline DU 1670 & $1 / 1$ & $1 / 1$ & $2 / 2$ & $2 / 2$ & $1 / 1$ & $2 / 2$ & $2 / 2$ & $1 / 1$ & $1 / 1$ & $1 / 1$ & $2 / 2$ & $1 / 1$ \\
\hline DU 1753 & $1 / 1$ & $1 / 1$ & $2 / 2$ & $2 / 2$ & $1 / 1$ & $2 / 2$ & $2 / 2$ & $1 / 1$ & $1 / 1$ & $1 / 1$ & $2 / 2$ & $1 / 1$ \\
\hline DU 1776 & $1 / 1$ & $1 / 1$ & $2 / 2$ & $2 / 2$ & $1 / 1$ & $2 / 2$ & $2 / 2$ & $1 / 1$ & $1 / 1$ & $1 / 1$ & $2 / 2$ & $1 / 1$ \\
\hline DU 1777 & $1 / 1$ & $1 / 1$ & $2 / 2$ & $2 / 2$ & $1 / 1$ & $2 / 2$ & $2 / 2$ & $1 / 1$ & $1 / 1$ & $1 / 1$ & $2 / 2$ & $1 / 1$ \\
\hline DU 1782 & $1 / 1$ & $1 / 1$ & $2 / 2$ & $2 / 2$ & $1 / 1$ & $2 / 2$ & $2 / 2$ & $1 / 1$ & $1 / 1$ & $1 / 1$ & $2 / 2$ & $1 / 1$ \\
\hline DU 1839 & $1 / 1$ & $1 / 1$ & $2 / 2$ & $2 / 2$ & $1 / 1$ & $2 / 2$ & $2 / 2$ & $1 / 1$ & $1 / 1$ & $1 / 1$ & $2 / 2$ & $1 / 1$ \\
\hline DU 1845 & $1 / 1$ & $1 / 1$ & $2 / 2$ & $2 / 2$ & $1 / 1$ & $2 / 2$ & $2 / 2$ & $1 / 1$ & $1 / 1$ & $1 / 1$ & $2 / 2$ & $1 / 1$ \\
\hline
\end{tabular}


Table 4 (cont.)

\begin{tabular}{lcccccccccccc}
\hline \multirow{2}{*}{$\begin{array}{l}\text { Isolates } \\
\text { of } \text { P. halstedii }\end{array}$} & \multicolumn{10}{c}{ EST-derived markers } \\
\cline { 2 - 13 } & Pha6 & Pha39 & Pha42 & Pha43 & Pha54 & Pha56 & Pha74 & Pha79 & Pha82 & Pha99 & Pha106 & Pha120 \\
\hline DU 1865 & $1 / 1$ & $1 / 1$ & $2 / 2$ & $2 / 2$ & $1 / 1$ & $2 / 2$ & $2 / 2$ & $1 / 1$ & $1 / 1$ & $1 / 1$ & $2 / 2$ & $1 / 1$ \\
DU1915 M1 & $1 / 1$ & $2 / 2$ & $1 / 2$ & $1 / 1$ & $1 / 1$ & $1 / 1$ & $1 / 1$ & $3 / 3$ & $2 / 2$ & $1 / 1$ & $2 / 2$ & $1 / 1$ \\
DU1915 M2 & $1 / 1$ & $2 / 2$ & $1 / 2$ & $1 / 1$ & $1 / 1$ & $1 / 1$ & $1 / 1$ & $3 / 3$ & $2 / 2$ & $1 / 1$ & $2 / 2$ & $1 / 1$ \\
DU1915 M3 & $1 / 1$ & $2 / 2$ & $1 / 2$ & $1 / 1$ & $1 / 1$ & $1 / 1$ & $1 / 1$ & $3 / 3$ & $2 / 2$ & $1 / 1$ & $2 / 2$ & $1 / 1$ \\
DU1915 M5 & $1 / 1$ & $2 / 2$ & $1 / 2$ & $1 / 1$ & $1 / 1$ & $1 / 1$ & $1 / 1$ & $3 / 3$ & $2 / 2$ & $1 / 1$ & $2 / 2$ & $1 / 1$ \\
DU1915 M6 & $1 / 1$ & $2 / 2$ & $1 / 2$ & $1 / 1$ & $1 / 1$ & $1 / 1$ & $1 / 1$ & $3 / 3$ & $2 / 2$ & $1 / 1$ & $2 / 2$ & $1 / 1$ \\
DU1734 M1 & $2 / 2$ & $2 / 2$ & $2 / 2$ & $1 / 1$ & $1 / 1$ & $1 / 1$ & $2 / 2$ & $3 / 3$ & $1 / 1$ & $1 / 1$ & $2 / 2$ & $1 / 1$ \\
DU1734 M2 & $2 / 2$ & $2 / 2$ & $2 / 2$ & $1 / 1$ & $1 / 1$ & $1 / 1$ & $2 / 2$ & $3 / 3$ & $1 / 1$ & $1 / 1$ & $2 / 2$ & $1 / 1$ \\
DU1734 M3 & $2 / 2$ & $2 / 2$ & $2 / 2$ & $1 / 1$ & $1 / 1$ & $1 / 1$ & $2 / 2$ & $3 / 3$ & $1 / 1$ & $1 / 1$ & $2 / 2$ & $1 / 1$ \\
DU1734 M7 & $2 / 2$ & $2 / 2$ & $2 / 2$ & $1 / 1$ & $1 / 1$ & $1 / 1$ & $2 / 2$ & $3 / 3$ & $1 / 1$ & $1 / 1$ & $2 / 2$ & $1 / 1$ \\
DU1734 M8 & $2 / 2$ & $2 / 2$ & $2 / 2$ & $1 / 1$ & $1 / 1$ & $1 / 1$ & $2 / 2$ & $3 / 3$ & $1 / 1$ & $1 / 1$ & $2 / 2$ & $1 / 1$ \\
\hline
\end{tabular}

No correlation was detected between five EST haplotypes (Table 4 and Fig. 2) and morphological characteristics (Table 3) for $P$. halstedii races used in our experiment. In accordance with our results, Mahdizadeh et al. (2011) reported no correlation between genetic diversity based on inter simple sequence repeat (ISSR) markers and morphological characteristics for Macrophomina phaseolina. However, regarding Sphaeropsis sapinea, De Wet et al. (2003) found that phenotypic groups A, B and C were separated into three differential genetic clades, by using multiple gene genealogies inferred from partial sequences of six protein-coding genes and six microsatellite loci.

No correlation was detected between pathogenicity traits (Tables 1 and 2) and EST haplotypes (Table 4 and Fig. 2). Indeed, for P. halstedii, Sakr (2011a) found no correlation between aggressiveness traits and EST genotypes. The lack of matching between virulence and aggressiveness traits and groups based on molecular markers was not surprising. Indeed, Montarry et al. (2006) did not find a clear correlation between pathogenicity phenotypes and genotypes based on Amplified fragment length polymorphism (AFLP) markers for Phytophthora infestans. Pathogenicity is known to evolve through mutation without highly altering molecular fingerprints (Goodwin 1997). Because most molecular markers used for fingerprinting are selectively neutral, they can be used to assess evolutionary forces other than selection (such as gene flow or genetic drift). Since tools for classification of obligate parasitic Peronosporaceae are very limited (Spring \& Thines 2004), it appears desirable to continue research for new methods. It is necessary to underline morphological, pathogenic and genetic variability on a large collection of $P$. halstedii isolates with different races from several parts of the world to provide a better insight into interactions between this obligate parasite and its host.

\section{ACKNOWLEDGEMENTS}

This study was done at INRA Clermont-Ferrand; we thank all persons who helped to perform this work. We gratefully thank Jalal Al-Attar for statistical helping.

\section{BIBLIOGRAPHY}

As-Sadi, F.; Carrere, S.; Gascuel, Q.; Hourlier, T.; Rengel, D.; Le Paslier, M. C.; Bordat, A.; Boniface, M.C.; Brunel, D.; Gouzy, J.; Godiard, L. \& VincourT, P. 2011. Transcriptomic analysis of the interaction between Helianthus annuus and its obligate parasite Plasmopara halstedii shows single nucleotide polymorphisms in CRN sequences. BMC Genomics 12: 498.

De Wet, J.; Burgess, T.; SlipPers, B.; Preisig, O.; Wingfield, B.D. \& WingField, M. J. 2003. Multiple gene genealogies and microsatellite markers reflect relationships between morphotypes of Sphaeropsis sapinea and distinguish a new species of Diplodia. Mycol. Res. 107(Pt 5): 557-566.

Delanoë, D. 1972. Biologie et épidémiologie du mildiou du tournesol (Plasmopara helianthi Novot.). Informations Techniques CETIOM 29(4): 1-40.

Delmotte, F.; Giresse, X.; Richard-Cervera, S.; M'Baya, J.; Vear, F.; Tourvieille, J.; Walser, P. \& Tourvieille de 
LABROUHE, D. 2008. Single nucleotide polymorphisms reveal multiple introductions into France of Plasmopara halstedii, the plant pathogen causing sunflower downy mildew. Infect. Genet. Evol. 8(5): 534-540.

GHASOLIA, R. P. \& AsHA, S. 2007. Morphological and pathogenic variability in rapeseed and mustard isolates of Sclerotinia sclerotiorum. Indian Phytopthol. 60(1): 76-81.

Giresse, X., TourvieIlle de Labrouhe, D.; Richard-CerveRA, S.; Delmotte, F. 2007. Twelve polymorphic ESTderived markers for Plasmopara halstedii, the causal agent of sunflower downy mildew. Mol. Ecol. Notes 7(6): 1363-1365.

Goodwin, S. B. 1997. The population genetics of Phytophthora. Phytopathology 87(4): 462-473.

Gulya, T. J.; Rashid, K. Y. \& Masirevic S. M. 1997. Sunflower diseases. In: A. A. Schneiter (Ed.), Sunflower Technology and Production 35: 263-379. Wisconsin, USA, Amer. Soc. Agronomy.

HaLL, G. 1989. CMI Descriptions of pathogenic fungi and bacteria, Set 98, Nos. 971-980. Mycopathologia 106(3): 183-211.

Jin, L. \& ChaKRABoRTY, R. 1993. Estimation of genetic distance and coefficient of gene diversity from single-probe multilocus DNA fingerprinting data. Mol. Biol. Evol. 11(1): 1112-1114.

KulKarni, S.; Hegde, Y. R. \& Kota, R. V. 2009. Pathogenic and morphological variability of Plasmopara halstedii, the causal agent of downy mildew in sunflower. Helia 32(50): 85-90.

LiBRADO, P. \& RoZAS, J. 2009. DnaSP v5: a software for comprehensive analysis of DNA polymorphism data. Bioinformatics 25(11): 1451-1452.

LEPPIK, E. E. 1966. Origin and specialisation of Plasmopara halstedii complex on the Compositae. FAO Plant Protection Bulletin 14(3): 72-76.

Islam, S. Z.; Badadoost, M.; Lambert, K. N.; Ndeme, A. \& FouLY, H. M. 2004. Characterization of Phytophthora capsici isolates from processing pumpkin in Illinois. Plant Dis. 89(2): 191-197.

MahdiZAdeh, V.; SAFaie, N. \& GolTapen, E.M. 2011. Diversity of Macrophmina phaseolina based of morphological and genotypic characteristics in Iran. Plant Pathol. J. 27(2): 128-137.

Montarry, J.; Corbiere, R.; Lesueur, S.; Glais, I. \& AndriVoN, D. 2006. Does selection by resistant hosts trigger local adaptation in plant-pathogen systemes? J. Evol. Biol. 19 (2): $522-531$.

MontarRY, J.; Hamelin, F.M.; Glais, I.; CoRbiere, R. \& ANDRIVON, D. 2010. Fitness costs associated with unnecessary virulence factors and life history traits: evolutionary insights from the potato late blight pathogen Phytophthora infestans. BMC Evol. Biol. 10: 283.

Nishimura, M. 1922. Studies in Plasmopara halstedii. I. The infection of Helianthus annuus L. by zoospores. J. Coll. Agric. Hokkaido Imp. Univ. Sapporo 11(3): $185-210$
Novotelnova N. S. (Eds): 1966. Downy mildew in sunflower. Nauka AS, Moscow.

SACKSTON W. E. 1981. Downy mildew of sunflower. Academic Press, London.

SAKR, N. 2009. Variation in aggressiveness of Plasmopara halstedii (sunflower downy mildew). J. Plant Dis. Protect. 116(6): 247-251.

SAKR, N. 2010. A plant mixture model aganist Plasmopara halstedii (sunflower downy mildew). J. Plant Protect. Res. 50(2): $125-129$.

SAKR, N. 2011a. Evolution of pathogenicity in Plasmopara halstedii (sunflower downy mildew). Arch. Phytopathol. Plant Protect. 44(15):1432-1436.

SAKR, N. 2011b. Relationship between aggressiveness and zoosporangia viability in Plasmopara halstedii (sunflower downy mildew). Arch. Phytopathol. Plant Protect. 44(16): 1585-1594.

SAKR, N. 2012. Virulence cost in Plasmopara halstedii (sunflower downy mildew). Arch. Phytopathol. Plant Protect. 45(6): 646-651.

SAKR, N. 2014. Evolution of new Plasmopara halstedii races under the selection pressure with resistant sunflower plants: A review. Hellenic Plant Protect. J. 7(1): 1-13.

Sakr, N.; Ducher, M.; Tourvieille, J.; Walser, P. \& Tourvieille DE LABROUHE, D. 2007. A new method to obtain monozoosporangial isolates of sunflower downy mildew (Plasmopara halstedii). Cryptogamie, Mycol. 28(2): 123-131.

Sakr, N.; Ducher, M.; Tourvieille, J.; Walser, P.; Vear, F. \& TourVIeille de LaBRouhe, D. 2009. A method to measure aggressiveness of Plasmopara halstedii (sunflower downy mildew). J. Phytopathol. 157(1): 133-136.

Sakr, N.; Tourvieille de Labrouhe, D.; Walser, P.; Ducher, M.; Delmotte, F.; Tourvieille, J. \& Vear, F. 2011. Analyzing the influence of qualitative resistance selection pressure on variation of aggressiveness in Plasmopara halstedii. J. Plant Protect. Res. 51(2): 140-144.

Snedecor, G. W. \& Gochran, W. G. 1989. Statistical Methods. The Iowa State University Press, Iowa.

Spring, O.; Bachofer, M.; Thines, M.; Riethmuller, A.; GoKER, M. \& OBERWINKLER, F. 2006. Intraspecific relationship of Plasmopara halstedii isolates differing in pathogenicity and geographic origin based on ITS sequence data. Eur. J. Plant Pathol. 114(3): 309-315.

SpRING, O. \& ThINES, M. 2004. On the necessity of new characters for classification and systematics of biotrophic Peronosporamycetes. Planta 219(5): 910-914.

Spring, O.; Voglmayr, H.; RiethMüller, A. \& OBerwinkler, F. 2003. Characterization of a Plasmopara isolate from Helianthus x laetiflorus based on cross infection, morphological, fatty acids and molecular phylogenetic data. Mycol. Prog. 2(4): 163-170.

Tourvieille de Labrouhe, D.; Bordat, A.; Tourvieille, J.; Mestries, E.; Walser, P.; SAKr, N.; Ducher, M.; DelmotTE, F. \& VEAR, F. 2010. Impact of major gene resistance management for sunflower on fitness of Plasmopara halstedii 
(downy mildew) populations. Oleagineux, Corps Gras, Lipides 17(1): 56-64.

Tourvieille de Labrouhe, D.; Pilorge, E.; Nicolas, P. \& VEAR, F. 2000. Le mildiou du tournesol. CETIOM-INRA Publications, Versailles.

Tourvieille de Labrouhe, D.; Serre, F.; Roche, S.; Walser, P. \& Vear, F. 2008. Quantitative resistance to downy mildew (Plasmopara halstedii) in sunflower (Helianthus annuus). Euphytica 164(2): 433444.

Van der Plank, J. E. 1968. Disease resistance in plants. Academic Press, New York and London.

VIRANYI, F. 1992. Plasmopara halstedii. In: EPPO Data Sheets on Quarantine Pests: 612-617. 